\title{
ANCIENT RITUALS AND THEIR PLACE IN THE MODERN WORLD: CULTURE, MASCULINITY AND THE KILLING OF BULLS - PART ONE
}

\author{
Stephen Allister Peté \\ BA LLB LLM MPhil \\ Associate Professor, Howard College Campus \\ University of KwaZulu-Natal, Durban \\ Angela Diane Crocker \\ BSc LLB LLM \\ Lecturer in Law, Howard College Campus \\ University of KwaZulu-Natal, Durban \\ Attorney of the High Court of South Africa
}

\section{SUMMARY}

Each year in KwaZulu-Natal, South Africa, a ceremony is held by the Zulu people in honour of the "first fruits". A certain part of what is known as the Ukweshwama ceremony involves the ritual killing of a bull by young Zulu warriors with their bare hands. The ritual is opposed by certain animal rights campaigners, who believe it is cruel to the animal which is sacrificed. A highly polarized debate has arisen between those opposed to any form of cruelty to animals on the one hand, and those seeking to defend ancient cultural practices on the other. The purpose of this article is to explore whether or not ancient rituals such as the ritual bull-killing at the Ukweshwama ceremony have a place in the modern world, and to interrogate the implications of the dispute which has arisen for the development of South Africa's constitutional democracy. The article is in two parts. Part One provides a brief synopsis of the importance of cattle within traditional Zulu culture and traces the public controversy surrounding the bull-killing ritual in KwaZulu-Natal. It also examines the legal arguments put before court on the issue, and discusses the origins in antiquity of certain of the main myths and rituals concerning bulls and bullkilling. Part Two compares and contrasts the respective controversies surrounding the Ukweshwama bull-killing ritual on the one hand, and Spanish bullfighting on the other. It also examines the wide range of positions adopted by philosophers and legal scholars vis-a-vis difficult questions of animal rights and cruelty to animals. The two sides of the argument are weighed up and tentative conclusions reached.

During the past number of years in KwaZulu-Natal, South Africa, a public controversy has arisen each year, which is centred on the annual "first-fruits" 
ceremony of the Zulu people. The Ukweshwama ceremony, as it is known to the Zulus, is a kind of traditional thanksgiving which takes place before the harvesting of crops and lasts for several days. ${ }^{1}$ As well as marking the beginning of the harvest, the ceremony symbolizes the rebirth of the monarch after a period of seclusion. ${ }^{2}$ While much of the ceremony is uncontroversial, there is one aspect of the ceremony that has caused temperatures to rise, angry letters to be written to the press, and urgent applications to be brought before court. The part of the ceremony that has caused the controversy involves the ritual killing of a bull by young Zulu warriors with their bare hands. According to historian, Professor Jabulani Maphalala, the killing of the bull represents a symbolic killing of the Zulu King. Maphalala explains that:

"[f]rom ancient times it is believed that the power of the King wanes and while in olden times the King was killed and a new King was installed, the modern practice developed of killing the King symbolically, so that this power may be regained and he would be revitalized."

In current ceremonies, the bull symbolizes the present Zulu monarch, King Goodwill Zwelithini. ${ }^{4}$ The bull is specifically chosen for its strength and, according to tradition, the power of the young warriors in overcoming the bull is symbolic of the power that the King wields over the Zulu nation. Since the bull represents the King, the ritual killing of the bull is not meant to involve mutilation. ${ }^{5}$ According to Maphalala, the young men overpower the bull "by closing its airways and thereafter its neck is broken in a specific manoeuvre that causes a quick and painless death. No bloodletting of any kind is allowed nor is dismemberment of any kind whatsoever part of the ritual slaying." It is believed that the process of killing the bull transfers the strength of the animal to the young warriors. This strength is in turn symbolically transferred to the King on his emergence from seclusion. ${ }^{7}$

1 In 2010 the ceremony started in early November and culminated in the festival on 5 December. Oellermann "Premier's Aide: Cruelty Claim 'Distorts' Bull Slaughter Ritual" 1 December 2009 Witness 1.

2 See Ka'nkosi "What a Load of Bull!" 3 December 2009 City Press 10.

3 Case no 10237/2009 12.

4 The link between rituals involving bulls and kingship is not unique to the Zulu people. In his book The Greek Myths, Robert Graves comments as follows on similar rituals conducted by the ancient Greeks: "The combat with a bull, or a man in bull's disguise - one of the ritual tasks imposed on the candidate for kingship ... - also appears in the story of Theseus and the Minotaur ... and of Jason and the fire-breathing bulls of Aeëtes ... When the immortality implicit in the sacred kingship was eventually offered to every initiate of the Dionysian Mysteries, the capture of a bull and its dedication to Dionysus Plutodotes ('giver of wealth') became a common rite both in Arcadia ... and Lydia ... where Dionysus held the title of Zeus. His principal theophany was as a bull, but he also appeared in the form of a lion and a serpent ... Contact with the bull's horn ... enabled the sacred king to fertilize the land in the name of the Moon-goddess by making rain - the magical explanation being that a bull's bellow portended thunderstorms, which rhombi, or bull-roarers, were accordingly swung to induce." Graves The Greek Myths - Volume Two (1957) 122.

5 Case no 10237/2009 13.

6 Case no 10237/2009 12. The ceremony includes a religious aspect, which centres on a thanksgiving rite during which the tribal ancestors are thanked for the safe arrival of the harvest and are called upon to share in the feast.

7 Ka'nkosi 3 December 2009 City Press 10. 
Not everyone, however, accepts this version of what happens when the bull is killed. Certain animal rights groups believe that the practice is cruel and amounts to torture of the animal concerned. Allegations have been made that the ritual involves choking the bull with sand, gouging out its eyes, and mutilating its genitals, before the animal finally dies. ${ }^{8}$ Needless to say, the debate has become extremely heated and highly polarized, between those advocating animal rights on the one hand, and those seeking to defend ancient cultural practices on the other.

The controversy surrounding ritual bull-killing in KwaZulu-Natal illustrates, perhaps, one of the many fault lines which fracture contemporary South African society - a clash between past and present; between pre-modern and modern; between African and Western; between Black and White; and, of course, between Animal Rights and Cultural Rights. ${ }^{9}$ It will be argued in this article that the heated debates which have arisen around the Ukweshwama ceremony reveal just such a clash of narratives. The article will explore the following central questions: Do ancient rituals have a place in the modern world, and what are the implications of the particular dispute under discussion for the development of South Africa's constitutional democracy? To answer these questions, an effort must to made to disentangle the different legal, historical, political and philosophical strands which connect the various narratives which make up this complex story.

The article will begin with a brief synopsis of the importance of cattle within traditional Zulu culture, and will trace the public controversy surrounding the bull-killing ritual in KwaZulu-Natal. The application to court in 2009 for an interdict by a group advocating animal rights, in an effort to prevent the bull-killing ceremony from taking place, will then be discussed. The legal arguments made by the opposing parties in this matter will be analysed, together with the finding of the court. Thereafter, the article will turn to a discussion of the origins in antiquity of certain of the main myths and rituals concerning bulls and bull-killing. In this way, the article will seek to situate the Ukweshwama ceremony within a broad historical context. Following this, in order to situate the controversy which has arisen around the ceremony in KwaZulu-Natal within a contemporary global context, the second part of this article will compare and contrast the respective controversies surrounding the Ukweshwama ritual bull-killing ceremony on the one hand, and Spanish bullfighting on the other. One of the aims of this discussion will be to provide a sense of precisely what is at stake for those on the "cultural-rights" side of such arguments. The animal-rights side of the argument will then be examined in order to reveal the wide range of

8 Case no $10237 / 20096$. They also stated that South Africa is a signatory to the Terrestrial Animal Health Code of the World Organisation for Animal Health and, as such, must ensure that the slaughter of any animal outside an abattoir is carried out without causing undue stress to the animal, Article 7.5.1(1). Case no 10237/2009 6-7.

9 One of the present authors has written elsewhere of the manner in which these fault lines, which divide the so-called "rainbow nation", have resulted in a society frozen into different constituencies, each with its own narrative, unable to connect with each other, and unable to move beyond the conflicts of the past in a decisive manner. See Peté "South Africa's Quixotic Hero and His Noble Quest - Constitutional Court Justice Albie Sachs and the Dream of a Rainbow Nation" 2010 31(1) Obiter 1. 
positions adopted by philosophers and legal scholars vis-á-vis the difficult question of animal rights. Once again, it is hoped that this discussion will reveal what is at stake for those on that particular side of the argument. The second part of the article will conclude by weighing up the two sides of the argument and reaching certain tentative conclusions as to the manner in which the controversy surrounding ritual bull-killing in KwaZulu-Natal may be resolved.

\title{
2 THE IMPORTANCE OF CATTLE WITHIN TRADITIONAL ZULU CULTURE AND THE CONTROVERSY SURROUNDING RITUAL BULL- KILLING IN KWAZULU-NATAL
}

\author{
"We evolved together, cows and us. We are old, old companions."10 \\ "Throughout the world, countless cattle owners treat their land and animals \\ with a reverence far more sincere than the weekend platitudes of casual \\ environmentalists ..."
}

Cattle have traditionally played an important part within the cultural life of the Zulu people. Throughout history, Zulus have held their cattle in the highest regard, and these animals have always played a pivotal role within traditional Zulu communal life. ${ }^{12}$ They have been used to link families in marriage and legitimize children, as well as to underpin the concept of ancestor religion and the power of the chief. ${ }^{13}$ As a mark of the prestige and value bestowed upon these animals, no culling is practiced and ownership of cattle (including milking) may only vest in the male members of the tribe. Thus, animals forming part of the family herd are rarely killed for food and are used mainly as a source of dairy, as for the purpose of sacrifice to the ancestors. ${ }^{14}$

The scholars Marguerite Poland and David Hammond-Tooke point to the importance of the special relationship between traditional Zulu people and their cattle. They speak of the "spiritual and aesthetic significance of the cattle of the Zulu people" being evident "in the talk of men, proud to discuss their animals, their strength, virility, productivity, calving ability, quirks, humours and dispositions." ${ }^{15}$ Perhaps the most important social function of a

10 Rimas and Fraser Beef: The Untold Story of How Milk, Meat, and Muscle Shaped the World (2008) xii.

11 Rimas and Fraser Beef: The Untold Story of How Milk, Meat, and Muscle Shaped the World xviii.

12 "It seems that amaZulu also compared the homestead head and his wives with the bull and his cows. Johnny Clegg, the internationally known musician and anthropologically trained expert on Zulu customs, has recorded that the family head takes great care to rise and pass water each morning before his bull does. If he does not, it is believed that his authority over both human group and herd will be undermined." Hammond-Tooke "Cattle Symbolism in Zulu Culture" in Carton, Laband and Sithole (eds) Zulu Identities: Being Zulu, Past and Present (2008) 62-68 64.

13 Hammond-Tooke in Zulu Identities: Being Zulu, Past and Present 62.

14 Ibid.

15 Poland and Hammond-Tooke The Abundant Herds: A Celebration of the Cattle of the Zulu People (2003) 10. 
Zulu homestead's cattle, however, is to act as a bride-price for women, as they move from their father's homestead to that of their husband. Lobolo, the bride-price, is paid in cattle, and the head of the homestead is morally obliged to help his sons to make this payment. To compensate a homestead with cattle for the loss of a woman from that homestead seems fitting, since the woman's brothers may in their turn use those cattle to secure a wife. ${ }^{16}$

Another important function of cattle within traditional Zulu homesteads is to act as a link between the living and the dead. The traditional Zulu homestead consists of a number of beehive shaped huts clustered around a central cattle byre, or kraal, which constitutes the centre of the homestead. The cattle byre has great significance in Zulu culture for not only does it serve to protect the cattle, which are a valuable commodity, but it is also thought to house the ancestors of the homestead. It is the place in the homestead that animal sacrifices are performed in honour of the ancestors. ${ }^{17}$ Such sacrifices are thought to be necessary if it is believed that the ancestors have become angry. Rituals involving animal sacrifice must then be performed in order to appease them. Hammond-Tooke elaborates as follows:

"Typically this takes the form of a blood sacrifice involving cattle ... The sacrificial beast comes from the family herd and the ritual officiator is the senior male member of the family. At each ritual an invocation is made to the august dead clan members, who are expected, as a collectivity, to be present. The beast symbolises both a propitiatory gift of food and a total subjection to patrilineal authority."

Such sacrifices involve the use of a ritual spear kept on a sacred ledge (or umsamo) at the back of the great hut. It is believed that a spiritual force links the umsamo, the human world and the cattle byre. According to HammondTooke, this symbolism points to the fact that "there is a fundamental identity between the members of the homestead and their cattle" and that "[h]ousehold and herd are one, constituting a single community". ${ }^{19}$ Poland and Hammond-Tooke comment as follows on the deeply spiritual link between traditional Zulu tribesmen and their cattle:

"Cattle serve as a constant reminder of the vigilance of the departed and, in the role of mediator, they provide the link between the perceptible and the transcendental. It is not surprising, therefore, that, in traditional society, the animals which forged so vital and complex a link within and between the

16 Hammond-Tooke in Zulu Identities: Being Zulu, Past and Present (2008) 65. It is interesting to note that, "The primary aim of bridewealth was the transfer of rights to any children born of the union form the mother's group to that of the husband. It was the children who were all important." Poland and Hammond-Tooke The Abundant Herds: A Celebration of the Cattle of the Zulu People 31.

17 Hammond-Tooke in Zulu Identities: Being Zulu, Past and Present 63-64, quoting Holleman "Die Twee-eenheidsbeginsel in die Sosiale en Politieke Samelewing van die Zulu" 194014 Bantu Studies 31-75.

18 Hammond-Tooke in Zulu Identities: Being Zulu, Past and Present 66.

19 Hammond-Tooke in Zulu ldentities: Being Zulu, Past and Present 63-64, quoting Holleman 194014 Bantu Studies 31-75. 
communities of the living and dead, should have been closely observed, named and praised with such perception and precision.

This deep spiritual and personal link is also evident in the Zulu practice of giving individual names to each Sanga-Nguni beast. ${ }^{21}$ Hammond-Tooke elaborates on the naming practices of the Zulu people in relation to their cattle as follows:

"Each ... beast ... is not merely a commodity, but an individual animal with a distinct colour pattern, horn shape, gender, status and history. In a deep sense, amaZulu also regard each member of their herd as having a personality. This has resulted in a complex system of naming that uses metaphorical and appropriate analogies to express identity. For example, a cream beast, spotted lightly with rust, is known as (and is) 'the egg of the lark' ... Cattle may also be given individual names which describe some attribute or episode in their personal history or which may be honorific."

For all the reasons set out above, it is quite clear that the relationship between the Zulu people and their cattle is characterized by a deep reverence, and is a connection which is both complex and deeply nuanced. Therefore, it is not surprising that any form of controversy touching upon any aspect of this relationship gives rise to deep passions within those who value and respect Zulu tradition.

Deep passions have indeed been aroused, in recent years, with the ongoing controversy surrounding the ritual bull-killing which forms part of the Ukweshwama first-fruits ceremony in KwaZulu-Natal. It is instructive to trace, very briefly, the history of this controversy. The issue began to register in the public media towards the end of 2009. In September of that year, the feelings of animal-welfare organizations, led by a non-profit organisation called "Animal Rights Africa", were running so high that they petitioned the Pan-African Parliament and the South African government, urging these institutions to denounce the ritual bull-killing, and to recognize animals as "sentient, deserving of care, respect and protection". ${ }^{23}$ In November, a letter written on behalf of the organization "People for the Ethical Treatment of Animals" (PETA) was released by an Indian animal rights activist, Maneka Gandhi. In the letter, the animal rights group expressed concern that the ritual in question was "exempt from animal protection laws on the grounds of 'cultural liberty'." The activists argued that traditions should not be used as an excuse for cruelty and that an evolving society such as South Africa should not be seen as "barbaric and retrograde by clinging to the cruel ritual of Ukweshwama". ${ }^{24}$ On 25 November 2009 the following comment was posted on the Mail \& Guardian website which perceptively set out the issues at stake:

20 Poland and Hammond-Tooke The Abundant Herds: A Celebration of the Cattle of the Zulu People 108.

21 This is the name given to the robust Zulu indigenous cattle. Hammond-Tooke in Zulu Identities: Being Zulu, Past and Present 66-67.

22 Ibid.

23 Magwaza "Bull Killing Festival To Go On" 16 November 2009 The Mercury 4.

24 Sapa "Zuma Asked to End Bull-killing Ritual" 5 November 2009 Mail and Guardian Online www.mg.co.za/article/2009-11-05-zuma-asked-to-end-bullkilling-ritual accessed 2010-10-11. 
"Bull-killing raises the stakes on the South African culture debate. The media bring it into public light, the what, the how, the when. They drop it there in the midst of us like the bull itself and leave us at it. The oppositions are galvanised on their sides glaring at each other and hurling charges of inhumanness and cultural repression. The animal rights activists are going to court after trying several times to get a response from the royal Zulu House. An interdict will do little in the long run for the forces at play are larger than a court can handle. Yes, I said it, there are things in this country that run deeper and have power that can overwhelm our legal system ..."

On 1 December 2009 the controversy reached boiling point when the Animal Rights Africa Trust brought an application in the KwaZulu-Natal High Court for an interdict prohibiting the slaughtering of any animal at the upcoming Ukweshwama festival. With the fat truly in the proverbial fire, the debate exploded in the local press. A spokesman for the African National Congress, the ruling political party in South Africa, stated that, "[t]he first fruit harvest celebrations form part of the pillars of African culture and religion and are common to the indigenous people of South African [sic] as a whole". ${ }^{26} \mathrm{He}$ expressed concern at "the approach and the tone taken by those opposed to some of the cultural and traditional practices ... [the Zulu] ... people are practising ..." saying that: "The matter of cultures and practices of our people is a subject that is sacrosanct and sensitive and needs to be dealt with carefully and appropriately." ${ }^{27}$ Under the headline "What a load of bull! Animal activists 'intolerant to Zulu culture",28 one newspaper article summed up the controversy as follows:

"The battle over the right of Zulu warriors to wrestle a bull to its death with their bare hands in an ancient tradition to mark the First Fruits Festival before crops are harvested has pitched tradition against modernity, animal rights against cultural rights and raised questions about the principles of the rule of law in a democracy.'

The article pointed out that, on the one hand, Zulu nationalists condemned opposition to the ritual as an "example of intolerance towards black cultures ...", It quoted a university graduate as stating: "This is colonial arrogance at its best. How can people who have no clue on the subject run to courts on something they know next to nothing about?",31 On the other side of the debate, Animal Rights Africa vehemently denied that its actions were motivated by cultural intolerance, insisting that the organization was simply questioning the continued relevance of the cultural practice in question within the context of contemporary South Africa. Let us now proceed to a more detailed examination of the legal arguments put forward and the eventual finding of the court.

25 http://www.mg.co.za/article/2009-11-05-zuma-asked-to-end-bullkilling-ritual accessed 201008-24.

26 Creamer Media Reporter, ANC: Statement by Mathole Motshekga, African National Congress spokesperson, on bull-killing (01/12/2009) www.polity.org.za accessed 2010-0824.

27 Ibid.

28 Ka'nkosi 3 December 2009 City Press 10.

29 Ibid.

Ibid.

31 lbid. 


\section{THE LEGAL ARGUMENTS PUT FORWARD AND THE FINDING OF THE COURT}

The application was brought by eight trustees, in their capacity as such, of the Animal Rights Africa Trust, a public benefit, non-profit organization operating for the general benefit of animals and the environment. The five respondents cited in the matter were as follows: The first respondent was His Majesty King Goodwill Zwelithini Kabhekuzulu, who was sued in his capacity as the Zulu monarch for the Province of KwaZulu-Natal; the second respondent was the Minister of Co-operative Governance and Traditional Affairs; the third respondent was the Member of the Executive Council for Local government, Housing and Traditional Affairs, Province of KwaZuluNatal; the fourth respondent was the Premier of the Province of KwaZuluNatal; and the fifth respondent was the Minister of Police.

The main purpose of the application was to obtain an interdict prohibiting the slaughtering of a bull or any animal at the Ukweshwama festival which was to take place on 4 December 2009 at one of the palaces of the Zulu monarch in Nongoma, KwaZulu-Natal. The specific terms of the order sought by the trustees of the Animal Rights Africa Trust read as follows:

1 that the first respondent (His Majesty King Goodwill Zwelithini) is interdicted and restrained from causing or permitting a bull to be slaughtered or in any way ill-treated at Ukweshwama, the Festival of First Fruits;

2 that the first respondent (His Majesty King Goodwill Zwelithini) be directed to notify the fifth respondent (the Minister of Police) of the dates, times and venue at which Ukweshwama was to be held in December 2009;

3 that the fifth respondent (the Minister of Police) be directed to ensure that a representative of the South African Police Services is present at all times during Ukweshwama to ensure compliance with the provisions of paragraph 1 of this order; and

4 that the first respondent (His Majesty King Goodwill Zwelithini) be directed to pay the costs of the application.

In papers filed on behalf of the Animal Rights Africa Trust, trustee Stephanus Smit (the first applicant) admitted that he did not have personal knowledge of the manner in which the bull was killed at the Ukweshwama ceremony, since he himself had never witnessed the ritual being performed. He stated, however, that he believed that the bull was killed by a group of approximately 40 men using their bare hands. The bull's eyes, genitals and tongue were ripped out whilst it was still alive, and sand or mud was thereafter forced down its throat in an apparent attempt to suffocate it while it was trampled, kicked and beaten to death. The bull died after being subjected to such treatment for approximately forty minutes.

Smit averred that his belief was supported by the fact that the practice had been very widely reported on - so widely, in fact, that the event had become notorious. As evidence for his belief, he gave examples of information sent 
to the State President of South Africa and the South African Parliament, by organizations in India, London and Kenya, which described how the bull was slaughtered at the festival. He also cited various public pleas, in the form of petitions and websites, calling on the South African government to stop the animal cruelty that was alleged to occur during the Ukweshwama Festival.

The two main thrusts of Smit's argument were: firstly, that the killing of the bull constituted a contravention of South African legislation, being the Animal Protection Act, ${ }^{32}$ as well as international legislation, being the Terrestrial Animal Health Code ${ }^{33}$ and, secondly, that the applicants' freedom of conscience and belief, guaranteed by section 15(1) of the Constitution, was adversely impacted upon by the alleged act of cruelty.

According to Smit, the applicants had a constitutional right to their sincerely-held belief that animals must be protected and saved from cruelty and suffering at the hands of human beings, and that the slaughtering of the bull in an allegedly cruel manner, was an infringement of this constitutional right. He maintained that the application dealt with two competing interests: the right of the first respondent to participate in the cultural life of his choice, which involved the killing of a bull at the Ukweshwama Festival, and the right of the applicants not to have their cultural beliefs impacted upon by that same practice. Smit argued further that the primary manner in which a multicultural society could seek to attain "unity in diversity" was to observe the norms and standards prescribed by Legislature. He argued that the first respondent could not assert that he was exempted by his culture from the laws of the land. Smit claimed that:

"The applicants have the right to have their views not only tolerated, but accorded respect. More than mere tolerance of sincerely held beliefs is required under the Constitution: traditions and cultures must be engaged, the tolerator taking the tolerated group seriously and engaging it in dialogue."

In response to the applicants' claims, the respondents objected at the outset to the applicants' delay in bringing the application (despite the fact that the applicants must have known about the ceremony for some time). The respondents contended that the consequences of this delay were twofold:

1 that the respondents and community organizations with a direct and substantial interest in the practice of customary law, religion and culture

32 Specifically s 2(1)(a) of the Animal Protection Act 71 of 1962, which provides that any person who ill-treats ..., infuriates, tortures or maims or cruelly beats, kicks, goads or terrifies any animal; shall ... be guilty of an offence.

33 The Terrestrial Animal Health Code ("the code") of the World Organisation for Animal Health to which South Africa is a signatory and is therefore bound. The relevant provisions include: Article 7.1.2, in terms of which South Africa has committed itself to ensure "the welfare of ... animals to the greatest extent possible." Article 7.5.1(1), which provides that all animals slaughtered outside slaughter houses (abattoirs) should be managed to ensure that their slaughter is carries out without causing undue stress to the animals. Article 7.1.2, which recognizes that the "use of animals carries with it an ethical responsibility to ensure the welfare of such animals to the greatest extent practicable." Where the "welfare" of the animal is recognized as the freedom of the animal from, inter alia, fear and distress, physical discomfort, and pain and injury. The Code prescribes in detail the methods of "stunning" and slaughter which are acceptable, on animal-welfare grounds. 
had not been given sufficient time to properly reply to such an important matter, which concerned the Constitutional rights of the Zulu nation to practice their religion and culture and to observe their customs, and which was to establish a principle of substantial constitutional importance; and

2 that in delaying the application, the applicants had allowed the early preparations for the ceremony to continue and, since the bull-killing ritual is pivotal to the event, all of these preparations would have been done in vain. Interference at this late stage would result in such high emotions and an outpouring of anger that there was a danger of widespread unrest and civil disobedience.

The factual basis of the respondents' response was as follows:

Firstly, the respondents averred that none of the persons who had deposed to affidavits before the Court, on the methods used to kill the bull, had witnessed the ceremony itself. They contended that the applicant had relied on unsubstantiated reports, which were based on hearsay evidence from sources that held a "jaundiced and distorted view" of the Ukweshwama ceremony.

Secondly, the respondents maintained that the applicants had misconstrued the primary religious and cultural significance that the actual act of killing the bull had in the Umkhosi Ukweshwama religious period, which commenced in early November and continued into December.

The respondents substantiated their contentions above with the testimony of an historian, Professor Jabulani Maphalala, who maintained that: "The applicants' description of the bull's death in the founding affidavits is so disturbingly inaccurate that it bears no resemblance to the reality of Zulu custom." In his opinion the applicants' unsubstantiated claims about the Ukweshwama proceedings had "created a perception that ignored the special relationship that the Zulu people have with their animals" and had "portray[ed] the Zulu people as barbaric, uncultured and inhuman who subject animals to the most cruel form of torture under the auspices and encouragement of their King in the name of custom and tradition".

Maphalala went on to state that he personally had witnessed the ritual killing of a bull during the Ukweshwama ceremony and the bull was put to death in the usual way by twisting and breaking its neck without any mutilation or acts of cruelty, which acts would never be tolerated in the Zulu culture. According to Maphalala, the applicants had shown their contempt for Zulu tradition by ignoring royal protocol and emailing the King in person to enter into dialogue on the issue. In addition, the fact that the applicants had "proceeded from the premise that they have a right to interfere with the religious and cultural practices of others that they find intolerable to their own beliefs" displayed an intolerance of religious and cultural diversity. The Zulu nation was being called upon to justify its beliefs and cultural practices, which was particularly harmful to the development of a democracy based upon tolerance and promoting diversity.

Maphalala then explained the history and significance of the Ukweshwama ceremony. He said that, according to traditional law and 
custom, no individual was allowed to taste new corn or any of the fruits of the new year until sanctioned in a public formal ceremony, lasting several days, at the King's great town. The event culminated in a feast, in which the tribal ancestors were called upon to share. This was to thank them for the safe arrival of the harvest.

One of the first events of this thanksgiving ceremony, which lasted for several days, was the ritual slaying of a bull, specifically chosen for its strength, by a group of young warriors. The symbolic significance of this event could be traced back to ancient times when it was believed that, once the power of the King waned, he should be killed and a new King installed. In modern practice, the killing of the King was symbolized by the killing of a bull. This ritual slaying of a bull by a group of young boys approaching puberty was believed to allow the King to regain his power and be revitalized. Thus, the killing of the bull was deeply symbolic of the great power claimed by the King alone. His power was symbolized by the strength of the young warriors in over-coming the bull. This strength was assumed by the King and was symbolic of the power he wielded over the Zulu nation. The ritual slaying required the young warriors to control and then kill the animal with their bare hands, without the assistance of a rope, thong or weapon of any kind. The boys achieved this by first closing the bull's airways to overpower it and then quickly and painlessly breaking its neck in a specific manoeuvre. No bloodletting or dismemberment of any kind was allowed.

Finally, the respondents argued that since the applicants had directed their challenge at the actual bull-killing ritual itself, and not at the protection of the particular bull to be killed on 4 December 2009, the Zulu nation would be greatly prejudiced if the members of the traditional community could not perform the ritual. This potential prejudice was far greater than the potential prejudice to the applicants, who could proceed with their application even after the bull in question had been slaughtered. The respondents claimed that any delay of the event would have serious implications, in that those taking part in the ritual would be unable to complete the ceremony to achieve self-purification and salvation, and would not be able to enter the period of feasting to celebrate their rejuvenation. They would be forced to forego the right to engage in a practice that formed part of their religion and culture. The respondents argued that the interim relief could spark unrest and civil disobedience in the province. This was already evidenced by hostility to the application, and threatened grave harm to the public. The respondents submitted that, for these reasons, the balance of convenience did not favour the granting of the relief.

The Judge dismissed the application with costs, stating in his judgment that, although the application was of a sensitive nature affecting the rights of both the Applicants and Respondents, it was common cause that the Applicants were unable to obtain affidavits from eye-witnesses to the manner in which the bull was killed. The only eye-witness evidence was put up by the Respondents. In addition, although the applicants only sought interim relief, the effect of granting the relief sought would be final. In light of this, the Applicants were required to prove their right on a balance of probabilities and not simply prima facie. In the circumstances, the Judge 
held that the Respondents' version of the events forming part of the Umkhosi ukweshwama festival, particularly in light of the fact that it had been celebrated for generations, was to be preferred to that of the Applicants.

Further, the Judge held that, should the ritual killing be interdicted, and given the history of the Zulu nation, it "might just be the proverbial match under the powder keg". The interdict would prevent the symbolic transfer of power to the Zulu King and the Zulu nation would, symbolically, be left with a powerless King. The obvious manner in which to obtain consensus on the manner in which bulls in such rituals were to be slaughtered, was to approach the relevant authorities with a view to resolving the conflict between the Applicant and the representatives of the Zulu nation. ${ }^{34}$

Although, as indicated above, the application for the interdict in December 2009 was dismissed and the ritual went ahead, this did not end the matter.

34 It is open to question whether the applicants would have been more successful had they sought an order preventing the respondents from slaughtering the bull in such a way that the animal was ill-treated, infuriated, tortured, maimed, cruelly beaten, kicked, goaded or terrified, or that caused the animal to suffer undue stress. This order could, perhaps, have been linked to an order that a member of the National Society for the Prevention of Cruelty to Animals (NSPCA) be present at the ritual, to ensure that the animal was not made to suffer in any of the ways outlined above. This may have allowed the ritual sacrifice to continue, permitting those taking part to practice and enjoy their culture, while ensuring compliance with the Animal Protection Act. In fact, this is what transpired in 2007, when Tony Yengeni, a prominent politician, was questioned by the NSPCA on his intention to spear a bull and then slaughter it at a cleansing ceremony, which formed part of an ancient Xhosa ritual. The Minister of Labour, Membathisi Mdladlana, responded to the controversy by extending an invitation to Marcelle Meredith, executive director of the NSPCA, to attend the ceremony, so that she could confirm that the animal was not made to suffer. (See Robins From Revolution to Rights in South Africa: Social Movements NGO's \& Popular Politics after Apartheid (2008) 1-2.) Jody Kollapen, Chairman of the South African Human Rights Commission, suggested that the NSPCA take a more proactive approach. Rather than simply using criminal law, he urged the NSPCA "to engage in a public debate around the issue relating to culture and cultural liberty and ... the NSPCA's mandate to prevent cruelty to animals." (See "Yengeni Animal Slaughter Not Criminal - SAHRC" 23 January 2007 IOL News http://www.iol.co.za/news/south-africa/yengeni-animal-slaughter-notcriminal-sahrc-1.312056 accessed 2012-06-06.) The NSPCA did, in fact, meet with the Cultural Linguistic Rights (CLR) Commission and concluded that the NSPCA had been dragged unnecessarily into a political issue. (See "Yengeni Bull Row was 'Political'" 13 February 2007 IOL News http://www.iol.co.za/news/politics/yengeni-bull-row-was-political1.315068 accessed 2012-06-06.) Furthermore, Couzens and Bellengere, in analysing the dissenting judgment of Cameron JA in The National Council of Societies for the Prevention of Cruelty to Animals v Openshaw (2008 (5) SA 339 (SCA)), argue that the status and role of the NSPCA is wider than the "prevention of ill-treatment of animals by promoting their good treatment by man". Although this is certainly one of the NSPCA's objects, Couzens and Bellengere argue that the NSPCA needs to be more proactive in preventing cruelty to animals. They quote with approval Cameron JA, who states in the above-mentioned case that "animals have no voice of their own ... Like slaves under Roman law, they are objects of the law, without being its subjects". (See The National Council of Societies for the Prevention of Cruelty to Animals $v$ Openshaw supra 351 par 39 and 40.) Couzens and Bellengere point out that "this is the reason for the statutory creation of the NSPCA as the 'guardian and [the] voice' of animals". (See Couzens and Bellengere The Sacrificial Blesbok: Inching Toward Greater Understanding of Animal Welfare Law in South Africa: National Council of Societies for the Prevention of Cruelty to Animals v Openshaw (2008 (5) SA 339 (SCA)); and Natal Zoological Gardens (Pty) Ltd v Ezemvelo KZN Wildlife (unreported NPD 13 August 2009) 2012 18(1) The South African Journal of Environment Law \& Policy (forthcoming).) 
In August 2010 Animal Rights Africa decided to seek leave to appeal that decision, but the High Court in Durban dismissed their application on the grounds that they were unable to prove that there was any cruelty involved in the ritual. ${ }^{35}$ The dismissal of the application for leave to appeal did not serve to cool the passions inflamed by this issue, which continues to be debated at present. One indication of the strength of the passions aroused by the issue is to be found in the comments of Judge Nick van der Reyden, the judge who dealt with the application by Animal Rights Africa for leave to appeal. The judge stated that he was profoundly shocked by the public's reaction to his ruling. He revealed that he had received disturbing messages from members of the public about the issue, including one stating that he would "burn in hell for eternity". ${ }^{36}$ Clearly, therefore, the issue is one which may be expected to raise further public controversy and lead to further legal action in the future.

Having outlined the current controversy around the Ukweshwama bullkilling ritual, as well as certain of the recent legal developments in the matter, in the section which follows we attempt to trace the ancient origins of various bull myths and rituals. In order to understand the significance of the particular ritual in question, it is important to appreciate that it is not simply an isolated cultural practice peculiar to the Zulus, but is a ritual with shared historical roots, stretching back to the dawn of humanity. Therefore, in dealing with this particularly Zulu cultural practice in the context of presentday South Africa, it is submitted that we need to keep sight of the wider global and historical perspective.

\section{THE ANCIENT ORIGINS OF BULL MYTHS AND RITUALS}

"For millennia, we have painted, corralled, stolen, worshipped, slaughtered, and eaten the flesh of these muscled giants. We've levelled forests and raised temples for them. Civilizations have arisen on their backs and been fed on their milk. We've sculpted their genetics. And all those years, they've been changing us, too. Imagine our world without cattle, and you're not imagining our world. Cattle, second only to the ingenuity of humanity itself, built this astounding complexity of fields and cities, letters and money, banks and kings. And, indeed, of gods."

The origins of myth and ritual stretch back to Palaeolithic times, when early hunter-gatherers engaged in ritualistic ceremonies to help them prepare psychologically for the hunt. Although necessary for survival, it was not easy for these early hunters to kill the massive mammals that were their main source of nutrition, for they revered these great animals, whose terror in death was most humanlike, and whose "blood flowed like human blood". ${ }^{38}$ So, as a way of coming to terms with what felt like the murder of a fellow creature, these hunters created myths and rituals, which could impart

35 Liebenberg "Bull Killing: It's Time to Talk, Judge Urges 21 August 2010 Witness.

36 Ibid.

37 Rimas and Fraser Beef: The Untold Story of How Milk, Meat, and Muscle Shaped the World 9 .

38 Armstrong A Short History of Myth (2005) 29-30. 
meaning to such a violent act. ${ }^{39}$ Karen Armstrong explains the importance of ritual as follows:

"A myth is not a story that can be recited in a profane or trivial setting. Because it imparts sacred knowledge, it is always recounted in a ritualised setting that sets it apart from ordinary profane experience, and can only be understood in the solemn context of spiritual and psychological transformation ... Together with the rituals that break down the barrier between the listener and the story, and which help him to make it his own, a mythical narrative is designed to push us beyond the safe certainties of the familiar world into the unknown. Reading a myth without the transforming ritual that goes with it is as incomplete an experience as simply reading the lyrics of an opera without the music. Unless it is encountered as part of a process of regeneration, of death and rebirth, mythology makes no sense."

Thus, pre-modern man was able to appreciate instinctively that every hunt would involve the complimentary, but quite distinct, spheres of reason [logos], which informed the hunter on how to make the kill, and of myth [mythos], which prepared the hunter emotionally for the tragedy that was about to play out. According to Armstrong:

"In the pre-modern world, most people realised that myth and reason were complimentary; each had its separate sphere, each its particular area of competence, and human beings needed both these modes of thought. A myth could not tell a hunter how to kill his prey or how to organise an expedition efficiently, but it helped him to deal with his complicated emotions about the killing of animals .... From the very beginning, therefore, homo sapiens understood instinctively that myth and logos [reason] had separate jobs to do. He used logos to develop new weaponry, and myth, with its accompanying rituals, to reconcile himself to the tragic facts of life that threatened to overwhelm him, and prevent him from acting effectively."

39 Armstrong states that: "The first great flowering of mythology ... came into being at a time when homo sapiens became homo necans, 'man the killer', and found it very difficult to accept the conditions of his existence in a violent world." See Armstrong A Short History of Myth 29-30.

40 Armstrong $A$ Short History of Myth 36 . It is interesting to note that Burstyn talks of the athlete being a "living mythic symbol-bearer" and comments that the intense feelings and identification invoked by sport in both participants and spectators alike, resembles a religious experience more so than any other form of "human cultural practice". Burstyn The Rites of Men: Manhood, Politics, and the Culture of Sport (1999) 18. Burstyn states that: "[t]he embodied athlete has become, on a social scale, the living mythic symbol-bearer, and the idea of the athlete-hero is fundamental to the nature and success of sport. The sport nexus, with its vast bureaucracies and enterprises, depends on him and the symbolic and mythological services he performs through the ceremonies and rituals of sport. These combine competition, physical skill, strength, and display. This ritual practice generates and sustains a mythology - a set of story-beliefs about society and the cosmos - that is ideologically laden. The rituals and mythologies of sport are the account sport gives of the world, and the base on which its vast contemporary economies rise ... Rituals encode and transmit information about basic, ideal social arrangements. They are, as anthropologist Lucia Nixon has pointed out, 'an essential part of human culture'”. Burstyn The Rites of Men: Manhood, Politics, and the Culture of Sport 20, quoting Nixon "Rituals and Power: The Anthropology of Homecoming at Queen's" Summer 19872 Queen's Quarterly 312-313.

41 Armstrong $A$ Short History of Myth 32-33. Rimas and Fraser make a similar point when they state as follows: "Why cattle, and not other useful animals? ... It's tempting to think that we worship that which we most fear, and also what we most desire ... A Neolithic hunter venturing into the agrios to stalk a gigantic powerful animal performed more than just a dietary act ... No hunter would have approached the prospect of a bull hunt without feeling some sense of gravity. Fear had to weigh in the balance with a hunger for meat and for 
Even long after the Palaeolithic period, animal sacrifice continued to form part of ancient ceremonies as a way of honouring those animals that had given their lives for human beings and these sacrifices were central to almost all early religious systems. ${ }^{42}$

With the invention of agriculture around ten thousand years ago, these rituals were transformed and linked to the activities of early farmers. Karen Armstrong remarks that the advent of agriculture "led to a great spiritual awakening that gave people an entirely new understanding of themselves and their world". The Palaeolithic people came to view the earth as "a living womb", capable of sustaining all creatures. Then, fearful that the earth's power might be exhausted, rituals involving the symbolic throwing away of the first seeds of a harvest and leaving the first fruits unpicked, were designed to "recycle these sacred energies". ${ }^{43}$ Certain of these "first-fruit" ceremonies involved the sacrifice of bulls. Andrew Rimas and Evan Fraser comment that the ancient people believed that blood spilled on the earth had the magical power to renew nature and restore crops. In fact, "[t]o make the sun come up in the morning".

With the rise of civilization, bull cults and ritual bull-killing continued to exert a powerful hold on the human imagination. We may begin with what is perhaps the world's very first civilization - that of ancient Sumer - situated between the Tigris and Euphrates rivers in an area subsequently called Mesopotamia by the ancient Greeks, and known today as Iraq. In one of the world's very first epic poems, the Tales of Gilgamesh, we find reference to a famous bull-killing. The story concerns Gilgamesh, the legendary king of Uruk, who famously killed the Bull of Heaven. The poem portrays Gilgamesh as part god, part human, a "sort of Sumerian Hercules endowed with great strength and wisdom, architect, builder, and benefactor of his people". ${ }^{45}$ In somewhat romantic terms, Rimas and Fraser explain as follows how the epic battle between Gilgamesh and the Bull of Heaven came about:

"During one glamorous adventure, Gilgamesh attracted the eye of Ishtar, the love goddess ... Knowing her fickly nature, Gilgamesh rejected her advances, calling her a dangerous woman who destroyed all the objects of her lust. Furious, Ishtar stormed off to her father the sky god, and in a tantrum

social esteem." Rimas and Fraser Beef: The Untold Story of How Milk, Meat, and Muscle Shaped the World 51-52.

42 Armstrong A Short History of Myth 31.

43 Armstrong A Short History of Myth 43-44.

44 Rimas and Fraser Beef: The Untold Story of How Milk, Meat, and Muscle Shaped the World 63, citing De Heusch "The Symbolic Mechanisms of Sacred Kingship: Rediscovering Frazer" 19973 Journal of the Royal Anthropological Institute 213-232 219. The central importance of animal sacrifice during antiquity is emphasized by Karen Armstrong who states as follows: "People continued to feel unhappy about the slaughter and consumption of animals long after the Palaeolithic period. Central to almost all the religious systems of antiquity was the ritual of animal sacrifice, which preserved the old hunting ceremonies and honoured the beasts that laid down their lives for the sake of human beings." See Armstrong A Short History of Myth 31.

45 Bonet and Salcedo Bulls \& Bullfighting: History, Techniques, Spectacle (1966) 106. 
demanded use of the Bull of Heaven as a weapon against the mortal who spurned her ..."

The Bull of Heaven then descends from heaven and is wrestled to its death by Gilgamesh, with the help of his great friend Enkidu, in an epic battle.

Turning to ancient Egypt, the centre of the second of the world's first great civilizations, we find similarly strong links to bulls and bull cults from the beginning of the Neolithic period. The bull was initially revered as a symbol of fecundity and fertility, and thereafter became imbued with new religious meaning, incorporating solar and celestial theology. ${ }^{47}$ The most famous of the Egyptian bull gods was Apis, who was a symbol of fertility, and closely linked to Osiris, the god of plant life, fertile soil, and the arts and civilization. ${ }^{48}$ According to Eduardo Bonnet et al, an annual ritual sacrifice of a bull, which was cut into fourteen pieces and eaten by the faithful, was symbolic of the resurrection of Osiris and the rebirth of nature, including agrarian prosperity. A living sacred bull was then substituted for the dead bull as a symbol of the resurrection. $^{49}$

In India, where the third of the world's first great civilizations was situated, the bull was regarded as a fountain of life and, according to legend, the first man, manu, even changed himself into a bull in order to gain the attentions of an extraordinarily beautiful woman, Ida or Illa. ${ }^{50}$ Bulls have always been closely linked to the idea of sexual and reproductive virility. The idea of the bull as a symbol of fecundity is strongest with the three great gods of the Indian Trinity: Siva (both creator and destroyer), Brahma, and Vishnu. ${ }^{51}$

46 Rimas and Fraser Beef: The Untold Story of How Milk, Meat, and Muscle Shaped the World 56.

47 Thus, for instance, the cow was converted into the sacred animal of Hathor, Nut, Isis, and Nephthys. In the same way, the three famous bull gods, Apis, Mnevis, and Buchis, were transformed into complex gods related to, respectively, Osiris, Re-Atum, and Montu. See Bonet et al Bulls \& Bullfighting: History, Techniques, Spectacle 99.

48 According to Bonet et al "when the sacred toro Apis was in Nilapolis (Middle Eqypt) in transit to its residence in Memphis, the maidens uncovered their bellies in front of the god in order to let in its procreative influence". See Bonet et al Bulls \& Bullfighting: History, Techniques, Spectacle 100. Rimas and Fraser describe a statue of the bull god Apis as follows: "Among the unpacked corpses in the Egyptian collection at the Louvre, shuffled in between the melancholy sphinxes, there's a statue of the god Apis, or at least of one of his manifestations. At a height of four and a half feet, it's not an imposing work, but it is stately and possesses the detached funereal grace that the Egyptians found so potent. This is especially striking in the case of Apis because he's a bull. He stands one hoof forward in the familiar Egyptian stride, his limestone face set in the same serene expression we know from pharaoh's heads. But Apis is every inch an animal. His limestone shoulders, swag-belly, and snout are impeccably realized."

49 Bonet et al Bulls \& Bullfighting: History, Techniques, Spectacle 99 and100. See also Kennedy who states that: "The Apis bull was a god in both life and death. A black bull with a distinctive white marking, he was recognised, picked out and then pampered as the personification of Ptah, the creator god of Memphis. The very water that washed his hide was precious. Having reached his entirely natural death each bull was carefully mummified and then represented Osiris, god of the dead." Kennedy On Bullfighting (2000) 28-29.

50 Bonet et al Bulls \& Bullfighting: History, Techniques, Spectacle 112.

51 The tradition of this Trinity goes back to the pre-Aryan civilization of Harappa, which flourished between 2500BC and 1500BC. Bonet et al Bulls \& Bullfighting: History, Techniques, Spectacle 112. 
Siva, who appears with a white bull called Nandi, is essentially a god of fecundity. Such is the importance that has been bestowed upon the cow, that it has been regarded as the mother of the Indian peoples. The killing of a sacred bull or cow amounts to the destruction of the fountain of life and, as such, is seen as an abominable crime, the punishment for which is condemnation to hell "for as many years as there are strands of hair on the dead cow's body." 52

Bulls also play a central part in the creation myths of the Persians. These myths tell of two prime adversaries, Ormuzd, the source of Goodness and Light, and Ahriman, source of Evil and Prince of Darkness. Eduardo Bonet et al explain that, according to legend, Ormuzd created a bull containing "all the seeds of organic life", from which he extracted the first man, Gayomart, and ultimately two hundred and seventy-two species of animals. ${ }^{53}$

Turning to early Greek myth, the Minoan civilization based on the island of Crete bequeathed to us the story of Theseus and the Minotaur. Legend has it that King Minos prayed to the sea god Poseidon to send him a worthy victim to use as a sacrifice to the god. A magnificent white bull was sent in answer to the prayer. King Minos was so taken with the animal that he deceived Poseidon and kept the animal for his own breeding stock, replacing the sacrifice with an ordinary beast. Incensed by the deception, Poseidon caused Minos's wife, Pasiphae to fall in love with the bull. The result of their mating was a monster, the Minotaur. ${ }^{54}$ According to the myth, the Minotaur was eventually killed by the great Athenian hero Theseus, who found his way in and out of the famous labyrinth in which the Minotaur lived, by unravelling a magic ball of thread given to him by Ariadne, the daughter of King Minos. ${ }^{55}$

There must be grains of truth to this myth, since the Minoan civilization left frescos depicting bulls, located in the ruins of the palace at Knossos in Crete. The frescoes show young men and women gymnasts taking turns to

52 Bonet et al Bulls \& Bullfighting: History, Techniques, Spectacle 112. Rimas and Fraser point out that the reverence felt by the Hindus for their cattle to this day, sometimes to the point that prized cattle may be fed whilst families go hungry, is not only based on cult observances but also on purely practical grounds. Adult cows could still perform the useful act of having young which, in turn, could perform many additional vital functions for the family. Rimas and Fraser Beef: The Untold Story of How Milk, Meat, and Muscle Shaped the World 66-67.

53 Bonet et al Bulls \& Bullfighting: History, Techniques, Spectacle 110. This resonates with the Viking creation myth, which Rimas and Fraser describe as follows: "The Vikings told a story about Audumla, a cosmic bovine that suckled Ymir, the 'rime-giant' whose sweat was so fertile that it begat the races of the Earth." According to Snorri Sturluson's Prose Edda (the Viking equivalent of the Old Testament): "Straightaway after the rime dripped [from the primordial ice], there sprang from it the cow called Audumla; four streams of milk ran from her udders, and she nourished Ymir." See Rimas and Fraser Beef: The Untold Story of How Milk, Meat, and Muscle Shaped the World 10.

54 See Rimas and Fraser Beef: The Untold Story of How Milk, Meat, and Muscle Shaped the World 58-59. Robert Graves states that Theseus's struggle with the Minotaur "is best understood as a coronation rite: by magical contact with the bull's horn, he became capable of fertilizing the land, and earned the title of Potidan, or Poseidon, given to the Moongoddess's chosen lover". See Graves The Greek Myths - Volume Two 118.

55 Robert Graves points out that: "'Minos' was the title of a Cnossian dynasty, which had a skybull for its emblem ..." See Graves The Greek Myths - Volume One 345. 
somersault backwards over a charging bull. Rimas and Fraser graphically describe the most famous fresco as depicting:

"a red-pied bull romping through a team of three androgynous athletes. One of these youths-elaborately coiffed, kohl-eyed, wisp-ankled grabs the terror's horns. Another, smaller and browner than his companions, somersaults over the animal's back. The third awaits the jumper with outstretched arms, to catch the flying youth on the dismount. Three and a half thousand years ago, professional gymnastics involved regular goring."

Bull cults were also prominent during Roman times. For example, followers of the popular religion of Mithraism, which was officially adopted by the Romans in the time of Pompey, believed that Mithra was an Aryan god of light and the conqueror of a bull god. Legend has it that the spilling of the bull god's blood released such abundance that temples were erected in Mithra's honour. Mithra was worshipped using the sacrifice of bulls, which involved baptizing initiates with the warm blood of the freshly sacrificed bull, after which they were crowned with garlands of flowers. ${ }^{57}$ The extent and popularity of the Mithraic cult were vast. In fact, in the second and third centuries it is estimated that seven hundred temples could be found in the cities of Rome and Ostia alone. One can imagine the multitude of temples and consequent numbers of followers of the religion over the entire Roman Empire. ${ }^{58}$

The centrality of the bull to religious cults is, perhaps, best summed up by Rimas and Fraser who state as follows:

"Mithras disappeared with the Romans, but the image of the sacred bull preceded him by many millennia and lasted long after his cult gave way to Christ. Bulls have been the center of cult since cult began. It was the bull that

56 See Rimas and Fraser Beef: The Untold Story of How Milk, Meat, and Muscle Shaped the World 59. According to Robert Graves the frescoes could also have portrayed a religious rite in which the acrobats symbolized planets. Graves The Greek Myths - Volume One 347.

57 Kennedy On Bullfighting 29. Rimas and Fraser elaborate on Mithra's temples, saying that they, "were modelled on ... [a] ... cave and were very different from those of the popular state gods like Apollo or Jupiter whose temples boasted biologically correct marbles, fluted columns, and serenely ordered beauty. His adherents needed no such frivolities - just stone hunkered against the black, northern wind; deliberately graceless like the natural sanctums of the inner earth ... What happened inside Mithras's temples was a re-enactment of a mythological dinner. Mithras's art repeatedly shows a sacred picnic, often depicted on the reverse of the bull-sacrifice relief. Using the slain animal's skin as a blanket, the god shared a feast with Sol, the sun, before the pair ascended together into the heavens". Rimas and Fraser Beef: The Untold Story of How Milk, Meat, and Muscle Shaped the World 45-46, quoting Pliny the Elder Natural History translated by Healy (1991).

58 Rimas and Fraser Beef: The Untold Story of How Milk, Meat, and Muscle Shaped the World 44-45, quoting Beck "Entry on Mithras" in Hornblower and Spawforth (eds) The Oxford Classical Dictionary (2003). Hills reiterates the importance of animal sacrifice in ancient Greek and Roman religion, saying, "It is hard to overstate the importance of animal sacrifice in the religions of ancient Greece and Rome. By ritually killing an animal, any ordinary person could thank the gods, ask a favour or find out what they willed. Myths telling of the pleasure taken by the gods in human sacrifice were common in Greek culture; animals were sacrificed as a substitute ... The larger the number of animals, the more pleasing to the gods: a sacrifice of a hundred bulls was not unusual. The killing of animals was so fundamental that it was nearly impossible to oppose it without challenging traditional religion altogether." Hills Do Animals Have Rights? (2005) 8. 
ignited the first sparks of religion, long ago in the unrecorded night of history."

It is clear that such rituals have been practised in Africa since ancient times and continue to be practised in the present. One example is the ritual of the Swazi people of southern Africa who, each year, sacrifice a black bull at the winter solstice. Another is the bull-killing ritual of the Xhosa people which is performed as part of a cleansing ceremony. The ritual requires that the sacrificial animal is prodded with a spear before it is killed in order to make it "burp", a sound which indicates that the ancestors will accept the sacrifice of the animal. ${ }^{60}$ It is clear that the annual Ukweshwama "first-fruit" ceremony of the Zulu people in KwaZulu-Natal, together with its ritual bullkilling, is linked to similar rituals of other tribal groups and is deeply embedded in Zulu culture.

\section{CONCLUSION}

In Part One of this article, we have outlined certain of the reasons for the deep social, cultural, philosophical and legal rift that has developed around the bull-killing ritual which takes place each year as part of the Ukweshwama ceremony of the Zulu people in KwaZulu-Natal. We have described the cultural and spiritual importance of cattle within traditional Zulu culture, and have traced the respective legal arguments put forward when the matter was the subject of litigation in 2009. Finally, we have pointed out that the ritual in question is not an isolated cultural practice peculiar to the Zulu people, but that it seems to share historical roots stretching back to the dawn of humanity which are common to many cultures.

In Part Two of this article, we shall situate the controversy which has arisen around the ritual within a contemporary global context, by comparing and contrasting the Zulu ritual to Spanish bullfighting. This will provide a sense of precisely what is at stake for those on the "cultural-rights" side of the argument. We shall then look at the "animal-rights" side of the argument by examining the wide range of positions adopted by philosophers and legal scholars vis-á-vis the difficult question of animal rights. Once again, we hope to reveal what is at stake for those on that side of the argument. Our conclusion will attempt to chart a way forward within the context of South Africa's current legal framework, balancing the values to which the constitution binds all South Africans.

59 Rimas and Fraser Beef: The Untold Story of How Milk, Meat, and Muscle Shaped the World 48.

60 Robins From Revolution to Rights in South Africa: Social Movements NGOs \& Popular Politics after Apartheid 1 and 2. 